\title{
METHODOLOGICAL APPROACH TO MUTUALLY AGREED CORPORATE IMAGE MANAGEMENT AND ECONOMIC SECURITY OF ENTERPRISE
}

\author{
Inna Rudenko', Denis Darmostuk', Alina Kolesnyk ${ }^{3}$, Tetiana Bolotova ${ }^{4}$, Oleg Bogoyavlenskiy \\ Olha Halkina ${ }^{6}$, Viktoriia Pustova ${ }^{7}$
}

${ }^{1}$ Department of economics, management and administration, Kharkiv College of Trade and Economics, Kyiv National University of Trade and Economics, Kharkiv, Ukraine

innazin1791@gmail.com

ORCID: https://orcid.org/0000-0001-5940-2344

${ }^{2}$ Department of Tourism, Hotel and Restaurant Business and Humanitarian Disciplines, Kharkiv College of Trade and Economics, Kyiv

National University of Trade and Economics, Kharkiv, Ukraine

denisdarmostuk@ukr.net

ORCID: https://orcid.org/0000-0002-1897-1521

${ }^{3}$ Department of Foreign Languages, Kharkiv College of Trade and Economics, Kyiv National University of Trade and Economics,

Kharkiv, Ukraine

lala4ka@ukr.net

ORCID: https://orcid.org/0000-0002-9890-6040

${ }^{4}$ Department of economics, management and administration, Kharkiv College of Trade and Economics, Kyiv National University of Trade and Economics, Kharkiv, Ukraine

tatabolotova1975@gmail.com

ORCID: https://orcid.org/0000-0003-1414-880X

${ }^{5}$ Department of economics, management and administration, Kharkiv College of Trade and Economics, Kyiv National University of Trade and Economics, Kharkiv, Ukraine

olegland7@gmail.com

ORCID: https://orcid.org/0000-0002-0447-5295

${ }^{6}$ Cyclical commission of professional disciplines in accounting and taxation, Kharkiv State Socio-economic College, Kharkiv, Ukraine halkina-olha@ukr.net

ORCID: https://orcid.org/0000-0002-8792-5190

${ }^{7}$ Cyclical commission of professional disciplines in accounting and taxation, Kharkiv State Socio-economic College, Kharkiv, Ukraine brandenburg1656@gmail.com

ORCID: https://orcid.org/0000-0003-1838-3532

ARTICLE INFO

Article history:

Received date 02.03 .2021

Accepted date 20.04.2021

Published date 30.04.2021

Section:

Strategy and Management

DOI

10.21303/2313-8416.2021.001790

KEYWORDS

management

methodological approach

economic security

functional components

corporate image

threat

competitiveness

efficiency

\section{ABSTRACT}

The object of research: corporate image and enterprise economic security. Investigated problem: methodical approach to mutually agreed management of enterprise's image and its economic security.

The main scientific results: theoretical analysis of the opinions, which are presented in the scientific literature of enterprise economic security functional components and the mechanism of their formation, is carried out. The functional components of economic security related to the internal and external aspects of enterprise are studied in detail, and their close relationship with image components is determined. The stages of enterprise image management are schematically shown with taking into account the compliance of image economic security components levels.

The area of practical use of the research results: the need to adhere to certain sequence of actions aimed at forming a positive image and managing it in enterprises is emphasized. It is advisable to use an approach to the formation of corporate image with taking into account the targeted influence of management entities on the business environment.

Technological innovation: the enterprise economic security structure in the context of modern tendencies is proposed, the complex of measures which are recommended to be applied for enterprise image maintenance is determined.

Scope of application for technological innovation: practical activity of Ukrainian enterprises is in interconnection with other business environment participants.

C The Author(s) 2021. This is an open access article under the Creative Commons CC BY license

\section{Introduction}

1. 1. Object of research

The object of research is corporate image and enterprise economic security.

\section{2. Problem description}

One of the most important factors that can form stable and long-term enterprises competitive advantages is their image [1]. In addition, the image is important element of enterprise com- 
petitiveness, which affects on all aspects of its long-term survival and development at the market, including economic security [2]. Enterprises are forced to constantly maintaining their economic security, carefully monitoring the processes of uninterrupted production and sale of their products, protecting their markets and counteracting external and internal threats. Therefore, enterprise's effective image management process should be based on the diagnostics of its economic security. It provides the adaptive abilities of enterprises to change the conditions of economic activity and create conditions for their stable functioning and development at the market.

Theoretical and practical aspects of enterprise economic security diagnostics for certain period were considered by domestic and foreign scientists. According to the references review, the positive image formation is important competitive advantage and one of enterprise economic security factors. Some authors hypothesize that «enterprise economic security is substantial, complex concept. In general, it can be defined as various dangers and threats absence or the ability to prevent them, protect their interests and prevent losses below the critical limit» [3].

Different authors have different opinions about the number and composition of enterprise economic security functional components. Some authors mark out the cultural and legal component of the economic security level; they believe that their significance is almost twice higher than the financial component has [4]. In our opinion, the information in this regard is contradictory. Other authors in the system of enterprise economic security diagnostics focus on the business information verification, information resources cyber protection, information and communication technologies and systems [5]. Therefore, the recent research and publications analysis shows the need for additional substantiation of enterprise economic security functional components composition and the mechanism of their formation with taking into account the market and economic situation in Ukraine.

It should also be noted that the image effect issues on enterprise economic security are paid insufficient attention. The logical and consistent relation of the economic security components and enterprises image for the food industry enterprises was considered in the following thesis [6]. The author proves the fact of image effect on its economic security providing. However, the indices of economic security levels assessing are needed to be clarified. The analysis of the relationship between corporate image and enterprise economic security components is carried out in the following work [2]. However, according to the authors, the image effect on economic security is considered in some fragments.

\section{3. Suggested solution to the problem}

With taking into account scientific groundwork of scientists, let's consider it is necessary to study the relationship between image components and economic security, to clarify their levels assessment and to propose methodological approaches to their mutually agreed management.

The relevance and practical significance of issues of enterprises' effective image management for their economic security providing at the present stage determine the choice and study focus.

The study purpose is methodological approaches to enterprise effective image management developing in relation to its economic security state.

\section{Materials and methods}

For this research purpose achieving the following methods are also used: monographic during study of references, enterprise economic security and corporate image management practices; theoretical generalization, comparison and analogies - for study the functional components composition of enterprise economic security; abstract and logical - for theoretical generalizations implementation, conclusions formulation and new hypotheses substantiation; functional assessment - for relationship establishing between image components and enterprise economic security; comprehensive - for developing methodological approach to enterprise image and its economic security managing.

Economic security typical structure involves marking out the following functional components: financial; intellectual and personnel; technical and technological; political and legal; information; environmental; power; market [7,8]. Other authors mark out the intellectual and personnel components separately and do not take into account the market structure-forming element [9]. Let's believe that the personnel and intellectual components of economic security should not be 
separated, because the low level of these indices is indicated by the same features: the outflow and turnover of personnel, low skills and part-time activity. There is reason to believe that the intellectual component is part of the personnel component and should not be separated. As for the market component of economic security, it is quite important in modern business conditions, because it shows the compliance of internal opportunities for enterprise external development. If this component does not work properly, the market share, which is occupied by the enterprise, decreases, competitive positions weaken, lagging behind market requirements occurs and so on. All these displays can significantly weaken the enterprise image.

In works $[2,10]$ the authors consider that it is necessary to separate all economic security components into two groups: domestic and non-production. Domestic components include financial, intellectual, personnel, technological, legal and power components to internal production; non-production components include the following: market, interface, information; ecological. It indicates that new functional component of economic security appears - interface component, which characterizes enterprise interaction with economic counterparties (suppliers, intermediaries, investors, consumers, etc.). In our opinion, this component should be paid special attention from the enterprise image management point of view. After all, establishing relationships with all contact audiences of the enterprise provides long-term reliable relationships with them and positive corporate image formation.

The interface component threat is possible unpredictable changes in the conditions of interaction with enterprise economic counterparties. For undesirable results avoiding, it is important to determine the expectations of each of enterprise contact groups and vice versa. On the base of our research, let's consider that the approach to the corporate image formation is grounded with taking into account the targeted effect of management entities on the business environment participants (stakeholders) [1].

Particular attention in the enterprise image management process should also be paid to the economic security intellectual and personnel components formation. The important point in enterprise economic security proper level protecting is the problem of selection, training and motivation of the necessary personnel.

Slightly different structure of economic security is presented by the author, who considers three levels of economic security: current, tactical and strategic [11]. Let's consider that presented author's classification of the economic security components is contradictory. In our opinion, any structural element can under certain economic conditions change from tactical to strategic or current, and vice versa. It cannot be said, for example, that the indices of the intellectual and personnel component of economic security do not have strategic direction. It is one of the most promising and powerful tools for high level of economic security providing in the future and its strategic planning is very important. Therefore, in the context of modern trends, let's consider that the following structure of enterprise economic security is grounded (Fig. 1).

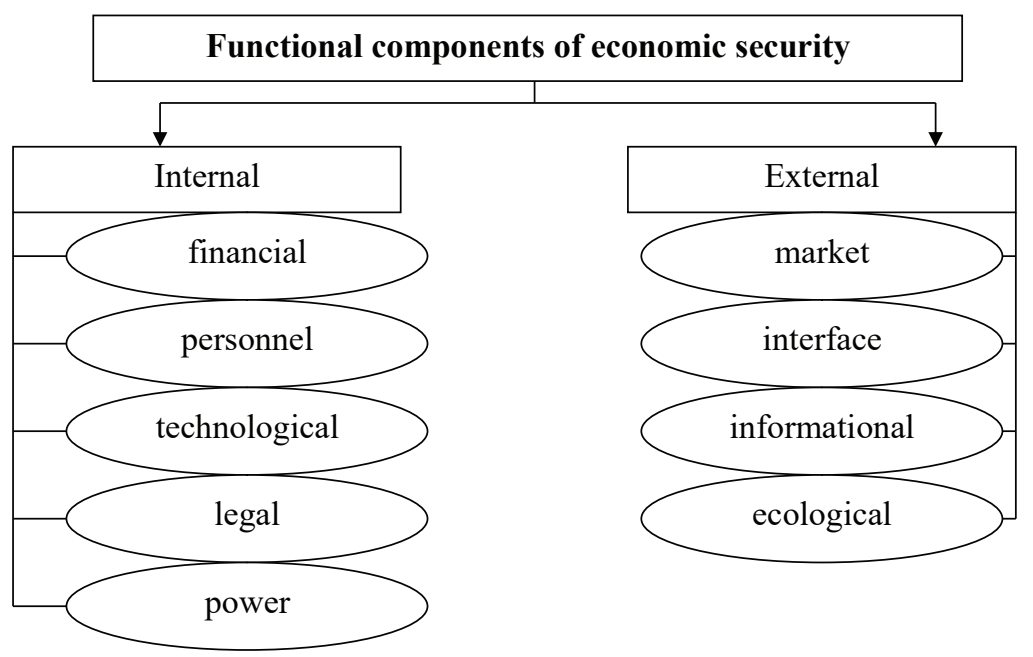

Fig. 1. Structure of enterprise economic security (it is developed by authors) 


\section{Results}

All economic security components, both internal and external, are interrelated with the corporate image. Let's take a closer look at these relationships.

The financial component characterizes the financial stability of the enterprise. If this component works properly, the enterprise increases liquidity and other financial and economic indices, receives investments and attracts new business partners. Because of these influences, the enterprise business image improves, namely, its business reputation (reliability, loyalty, prestige, openness, etc.). This component is very important for the enterprises positive image formation at both domestic and foreign markets. On the other hand, sufficiently high business image attracts investors and provides the financial stability of enterprise.

The economic security personnel component isn't less important for the positive corporate image formation; it characterizes the staffing supply and intellectual potential of employees. It, undoubtedly, has a positive effect on the enterprise's image in the business sphere, which, in turn, increases the attractiveness of the enterprise for new and more qualified personnel.

The next component of economic security is technological, which characterizes the enterprise technological potential, and, under its proper level, advanced technologies are used, innovative products are produced, their quality is improved. It provides high image of the product and positive business image of the enterprise in general. On the other hand, positive image provides uninterrupted production and the possibility to use new technologies, advanced types of products, new solutions which are used in the production process.

As for the legal component of economic security, it provides interests legal protection of both enterprises and employees. It, in turn, provides the safe work of workers and improves the enterprise social image. Personnel positive image also has corresponding effect on the legal component of economic security and stabilizes it.

The last internal component of economic security is the power component. «It characterizes the elimination of physical and moral influences from workers and enterprises interests» [10]. Negative influences damage the enterprise property, weaken the enterprise economic security and negatively affect on its social image. Physical and moral security of personnel and enterprise property protection provide positive image formation. For its part, the positive corporate image provides proper attention to the enterprise security. That is, according to this economic security component, two-way connection with positive image formation occurs.

The following functional components of enterprise economic security are connected with external aspects of its activity. The market component shows the compliance of internal opportunities to enterprise external development. It is very important under the competitive economy, which is shown by increasing the market share that is occupied by the enterprise, strengthening competitive positions, compliance with market requirements. Scientists recommend use SWOT-analysis for market security level diagnostics, which assesses the internal strengths and weaknesses of the enterprise, as well as its external threats and opportunities [12]. If diagnostics results reveal sufficient level of market security, it increases consumers' number and their loyalty. On the other hand, the positive corporate image increases the enterprise's competitive position at the market, strengthens the market component of economic security.

The interface component of economic security isn't less important for the positive corporate image formation; it characterizes the interaction of the enterprise with economic counterparties and contact audiences. Its proper level provides long-term relations of the enterprise and its corporate image improvement. The reverse effect of the positive image is shown under relations establishment between the enterprise and all contact audiences.

The rational system of enterprise informational support is very important for its economic security. Business risks reducing and enterprise confidence increasing are achieved on the base of economic information completeness and reliability providing. It provides the formation of the enterprise positive image, due to which, in turn positive information about the enterprise spreading and its competitive advantages increasing occur.

The last component of economic security is the ecological component, which shows the ecological state of the environment and the enterprise. This component has become especially relevant recently due to the environment deterioration at the global level. «If this component does not work properly, it is evidenced by loss of profits because of high environmental fines, threats 
to employees health, reduced competitiveness, etc.» [10]. Sufficiently high level of this component provides creation the image of the ecological products producer, which strengthens the positive social image of the enterprise. Feedback will be observed in the enterprise's adoption of environmental innovation.

The analysis and assessment results of the levels which make up economic security should be the basis for the methodological approach development to the mutually agreed management of image and economic security. Obviously, certain sequence of actions which are aimed at the enterprise positive image formation under unstable economic situation should be followed (Fig. 2).

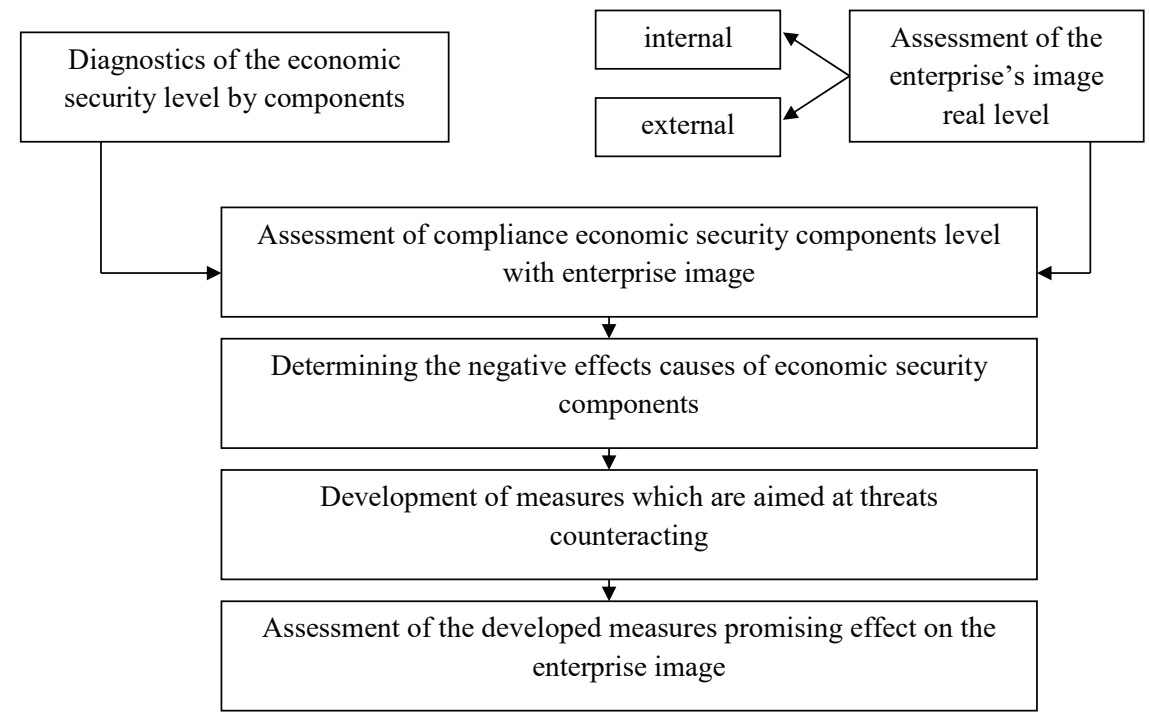

Fig. 2. Stages of enterprise image management (it is developed by authors)

\section{Discussion}

The references study on the research topic shows a lack of unity in the diagnostics methodology of enterprise economic security. A number of authors propose for economic security diagnostics to calculate the relative indices of financial stability and solvency. Others consider that it is necessary to use absolute indices of enterprise financial stability, bankruptcy and etc. But these indices reflect only one component of enterprise economic security it is the financial component. Personnel, intellectual, technical, information, etc. components are not taken into account. Let's consider that the enterprise economic security external and internal functional components are grounded (Fig. 1).

The study shows close relationship between the enterprise's image and all components of its economic security. «The high level of each component of economic security affects on the growth of enterprise image, on the other hand - the positive image provides economic security for each component individually and for enterprise as a whole» [6]. For diagnostics of each functional component of economic security, their analytical indices are selected and calculated [12], which can be used as base for developing methodological approach to mutually agreed image management and economic security (Fig. 2).

Regarding the specific measures that can be proposed for enterprise image providing, they are represented by the following sets of measures: personnel, marketing, clientele and production and economic [1]. It, in turn, will help expand the adaptive possibilities of enterprises to change the conditions of economic activity and create conditions for their stable functioning and development.

Further research by the authors should be aimed at developing formalized procedures to support the domestic enterprises corporate image and the selection of appropriate tools for their implementation.

\section{Conclusions}

The effective image management process of enterprise should be based on the enterprise economic security state diagnostics, which will allow the enterprise management system to be in a state of rapid response to threat signals from external and internal environments. 
The structure of enterprise economic security in the context of modern tendencies is studied. The functional components of economic security related to the internal and external aspects of the enterprise are studied in detail, and their close relationship with the components of the image is established.

According to the research results, the methodical approach to mutually agreed image management and economic security is proposed, which is based on the economic security levels diagnostics results and enterprise image real level assessment. Set of measures for enterprise image supporting is also proposed.

\section{References}

[1] Rudenko, I. V., Kulynych, T. V., Nepran, A. V. (2020). The Image of Trade Enterprise: Approaches to Its Formation. Business Inform, 4 (507), 464-471. doi: http://doi.org/10.32983/2222-4459-2020-4-464-471

[2] Illiashenko, S. M., Kolodka, A. V.; Khlobystov, Ye. V. (Ed.) (2013). Rol imidzhu u zabezpechenni ekonomichnoi bezpeky pidpryiemstva. Ekonomichna bezpeka derzhavy: mizhdystsyplinarnyi pidkhid. Cherkasy: Vydavets Chabanenko Yu. A., 436445. Available at: http://essuir.sumdu.edu.ua/handle/123456789/33440

[3] Kraievskyi, V., Tytenko, L., Paianok, T., Bohdan, S., Hmyrya, V. (2020). Accounting and analytical support for assessing the level of economic security of the enterprise. Financial and Credit Activity: Problems of Theory and Practice, 4 (35), 87-98. doi: http://doi.org/10.18371/fcaptp.v4i35.221801

[4] Kutsenko, V. Y. (2020). Methodology of diagnostics of economic security level of an enterprise. Economic Bulletin of the National Mining University, 69, 85-95. doi: http://doi.org/10.33271/ev/69.085

[5] Skrynkovskyy, R., Pawlowski, G., Harasym, P., Koropetskyi, O. (2017). Cybernetic Security and Business Intelligence in the System of Diagnostics of Economic Security of the Enterprise. Path of Science, 3 (10), 5001-5009. doi: http://doi.org/10.22178/ pos.27-6

[6] Fen, K. S. (2018). Formation and strengthening of economic safety of enterprises of the food industry. Kamianets-Podilskyi, 273. Available at: https://www.pdatu.edu.ua/images/naukova-miznarodna-diyalnist/svr/dissertaciya-fen.pdf

[7] Kosianchuk, T. F., Lukianova, V. V., Maiorova, N. I., Shvyd, V. V.; Kosianchuk, T. F. (Ed.) (2007). Ekonomichna diahnostyka. Lviv: Novyi Svit-2000, 452. Available at: https://uallib.org/book/2602164/e954b8?id=2602164\&secret=e954b8

[8] Pokropyvnyi, S. F. (Ed.) (2003). Ekonomika pidpryiemstva. Kyiv: KNEU, 608.

[9] Hetman, O. O., Shapoval, V. M. (2007). Ekonomichna diahnostyka. Kyiv: Tsentr navch. literatury, 307. Available at: http:// www.cul.com.ua/preview/Ekonom_diagnost-Getman.pdf

[10] Horodnia, T. A., Moiseienko, I. P. (2008). Ekonomichna ta finansova diahnostyka. Lviv: «Mahnoliia 2006», 282. Available at: http://www.magnolia.lviv.ua/?p=388

[11] Gichova, N. Y. (2010). The diagnostics and elevation of economic security ofenterprise. Dnipropetrovsk, 23. Available at: http://ir.nmu.org.ua/handle/123456789/76?locale-attribute=es

[12] Harkusha, N. M., Sidorova, T. O., Rudenko, I. V. (2009). Diahnostyka ekonomichnoi bezpeky pidpryiemstva. Ekonomichna stratehiia i perspektyvy rozvytku sfery torhivli ta posluh, 2 (10), 53-59. 